
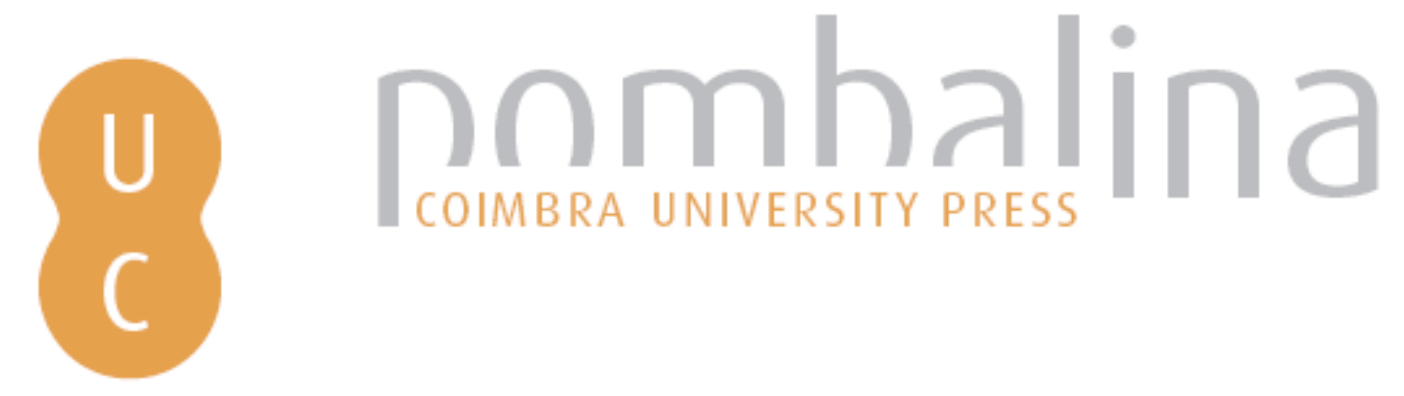

\title{
Sports in a changing society: the case of Portugal: origins, current statistics and new directions
}

\author{
Autor(es): $\quad$ Silva, Manuel Coelho e; Figueiredo, António; Gonçalves, Carlos E. \\ Publicado por: Imprensa da Universidade de Coimbra \\ URL \\ persistente: URI:http://hdl.handle.net/10316.2/32232 \\ DOI: $\quad$ DOI:http://dx.doi.org/10.14195/978-989-26-0474-9_2 \\ Accessed : $\quad$ 26-Apr-2023 01:12:14
}

A navegação consulta e descarregamento dos títulos inseridos nas Bibliotecas Digitais UC Digitalis, UC Pombalina e UC Impactum, pressupõem a aceitação plena e sem reservas dos Termos e Condições de Uso destas Bibliotecas Digitais, disponíveis em https://digitalis.uc.pt/pt-pt/termos.

Conforme exposto nos referidos Termos e Condições de Uso, o descarregamento de títulos de acesso restrito requer uma licença válida de autorização devendo o utilizador aceder ao(s) documento(s) a partir de um endereço de IP da instituição detentora da supramencionada licença.

Ao utilizador é apenas permitido o descarregamento para uso pessoal, pelo que o emprego do(s) título(s) descarregado(s) para outro fim, designadamente comercial, carece de autorização do respetivo autor ou editor da obra.

Na medida em que todas as obras da UC Digitalis se encontram protegidas pelo Código do Direito de Autor e Direitos Conexos e demais legislação aplicável, toda a cópia, parcial ou total, deste documento, nos casos em que é legalmente admitida, deverá conter ou fazer-se acompanhar por este aviso.

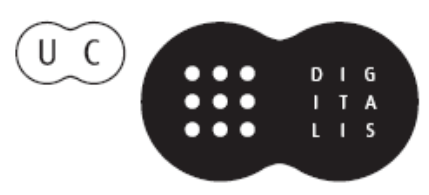


Carlos Eduardo Gonçalves

Sean P. Cumming

Manuel J. Coelho e Silva

Robert M. Malina

(Editors)

\section{Sport \\ and Education}

Oribute to OMaxtin Lee

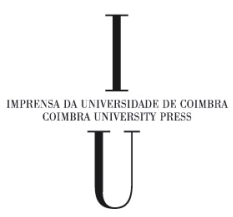


Manuel Coelho e Silva; António Figueiredo; Carlos E. Gonçalves

University of Coimbra, Portugal

\section{SPORTS IN A CHANGING SOCIETY - THE CASE OF PORTUGAL: origins, current statistics and new directions}

\section{Introduction}

In contemporary society there are few individuals who do not encounter elements of sport in their social lives, often on a daily basis. This is not only illustrated by an increase number of participants during the last decades but also by the expanding variety of sports and ways to pratice them.

The final decades of the monarchy witnessed the introduction of sports into Portugal. The phenomenon was mostly related to aristocrats and foreign communities living in the country while the popularization of sports was favoured by the social and cultural atmosphere emerged in the early XX Century with the Republic. The non-governamental sport expanded in the last quarter of the past century, especially after the end of the dictatorship.

It is difficult to organize chronological statistics for participation in sport in Portugal due to the lack of specific and uniform information. The present article examines the social environments and contexts that favoured the appearance, dissemination and differentiation of sports and attempts to interpret the trends of recently published statistics.

\section{Brief notes about the introduction of sports in Portugal}

\subsection{Involvement of the monarchy in sports in the transition from XIX to XX Centuries}

The main sports were introduced into Portugal in the second half of the $19^{\text {th }}$ century (gymnastics) and early $20^{\text {th }}$ century (football, basketball, hockey). This period coincided with the end of the monarchy, whose influence can be seen in reports published in important sports journals of the period ("Tiro e Sport"). In December 1906, a sport event was organised by a committee led by the Infante D. Afonso. Various awards bore names such as Her Majesty Queen Amelia or the Prince Luiz Filipe Award. Amongst the winners it was possible to identify Pinto Basto, a family also related to the organization of a soccer match in Belas by the end of the $19^{\text {th }}$ century. 
The introduction of new sports and creation of new clubs, in fact, were strongly related to the aristocracy. An example is Herbert Dagge, founder of a prominent sport organization, "Real Ginásio Clube Português" ('Royal Portuguese Gymnasium Club'); he is also known as the "father" of Portuguese cycling (Barroso, 2001).

According to Gouveia (2002), after some experimental roller hockey games held in 1905 in Carcavelos, due to the influence of the local English community, skating was performed at the Military College in 1908, and in a garage at the Street Alexandre Herculano belonging to the "Portuguese Society of Authors", where the "blue bloods" used to congregate. In the trophy room of the Portuguese Skating Federation is the pair of wooden skates used by the last king of Portugal, D. Carlos I.

The aristocrats supported the amateur ethos, and their clubs and tournaments were organized within a closed system. Sport started to be popularized after the establishment of the republic. An example of this was the classic Oporto-Lisbon cycling race, an event which was not free of controversy.

In the first year of the Republic, the Portuguese Cycling Union (União Velocipédica Portuguesa) received about 20 entries for the race Oporto-Lisbon but only three confirmed their participation. For this reason, the event was held for the first time on 5 November 1911. The first official winner was only recognized in 1912. Of interest, the winner in the previous year was disqualified for cheating. The event was annulled after confirming that three cyclists had been conspiring to commit irregularities with a view to dividing up the prizes.

\subsection{The influence of foreign communities in Portugal and of Portuguese living abroad}

Several new physical activities appeared in Portugal largely as a result of foreign influence. Examples were the first football matches held in Funchal (Island of Madeira, 1873 - Malta \& Jacinto, 2002) and in Oporto (1890, idem), both of which may have connections to the fortified wine industry (Madeira and Port, respectively), which was heavily dominated by British families established in Portugal.

In Oporto, the new social practice was widely diffused, leading to the rapid appearance of clubs like the Futebol Clube do Porto ("Oporto Football Club") only several years later. In Madeira, on the other hand, the native population contented themselves watching matches played by the crews of the cargo ships that would dock there. This suggests that the diffusion of new practices was largely dependent upon the sociocultural capital of the populations.

In Coimbra, a group of well-travelled university students apparently formed a team about 1876 (Gerardo \& Gomes Ferreira, 2002). There are records of a letter addressed to the Rector of the University of Coimbra requesting official permission to use a large piece of land for football matches. This suggests the expansion and generally spontaneous popularity of soccer.

It is believed that the younger and more educated groups were more dynamic in the introduction and adherence of new cultural habits. Students of the University of Coimbra played an important and pioneering role in popularizing sports. Further, the event that introduced football into the Lisbon area in 1884 was organized by the Pinto Basto brothers who studied in England and from where they had brought a ball (Malta \& Jacinto, 2002). 
The available historical data demonstrate the country's receptivity to football, which was introduced into different places independently. The Univesity of Coimbra possibly played an important role in spreading different sports around the country since its students came from different backgrounds both social class and geographic origin. Upon completing their degrees, they would often take the spirit of Coimbra back with them to their home towns or to wherever job opportunities would lead them (including overseas), establishing new clubs and thus contributing to the appearance of the numerous sporting organizations that bore the name "Academica".

\subsection{The colonization process}

Gymnastics was also associated to the academic milieu in Coimbra. In 1852, a student from the Faculty of Law, Pedro Roxa, founded the Sociedade Gymnastica ("Gymnastics Society") and set up a gymnasium on the second floor of a building in the centre of the city (Praça 8 de Maio). After this, several gymastics organizations appeared and subsequently disappeared after a short period, indicating that the enthusiasm of the founders was not enough to ensure the survival of the sport organizations, particularly in sports requiring technical supervision.

In fact, a succession of clubs occurred in the city of Coimbra. These included the Sociedade Gymnástica ("Gymnastics Society"), which closed in 1854; the Gymnásio Coimbra ("Coimbra Gymnasium"), founded in 1883 and closed in 1903 after various interruptions; and the Gymnásio Recreio ("Recreational Gymnasium"), founded by two local businessmen motivated to encourage physical exercise amongst the working classes, but which closed because of disagreements between the partners.

Mention should also be made for the Gymnásio Mouzinho de Albuquerque. This organization assumed the name of a Portuguese military officer and colonial governor that had won glory by capturing Gungunhana, a fearsome tribal leader in southern Mozambique. The popularity, even glorification, of Mouzinho de Albuquerque reflected efforts to refine the race. During this period, Portugal was a small country oriented toward colonization of territories spread across five continents. This ambitious task was systematically affected by a high incidence of infectious and contagious diseases such as influenza, leprosy and tuberculosis.

At the beginning of the $20^{\text {th }}$ century, gymnastics was believed to have positive properties and was associated to the hygienics of the era. This was exemplified by reports such as that cited by Gerardo \& Gomes Ferreira (2002) from the newspaper "O Conimbricense" (10 December 1902), concerning an exhibition of Swedish Gymnastics performed by students from state primary schools. The session involved different gymnastics exercises and military drills that seemed to have pleased the inspector, who was particularly impressed with the precision, elegance and harmony of the movements performed in response to commands issued by the 'patriotic teacher'.

In the Berlin Olympic Games of 1936, the display of the supremacy of the Aryan was, perhaps, at its highest. Attitudes towards race have subsequently changed. Today, Portugal is delighted with the medals won in the European Athletics Championships (held in Sweden in August 2006) by the Nigerian Francis Obikwelu (naturalised Portuguese) or the women's heptathlon winner, Naide Gomes (born in São Tomé). 
Analysis of the 20 members of the athletics team chosen for the last Olympic Games (Olimpo - Journal of the Portuguese Olympic Committee, 2004) showed that a substantial contingent of the athletes was born outside of Portugal. In addition to Obikwelu and Naide Gomes, the team also included Edivaldo Monteiro (Guinea Bissau), Maribel Gonçalves (Venezuela), Nelson Évora (Ivory Coast), Pedro Martins (Angola), and Carla Sacramento (Afro-Portuguese).

\subsection{From enthusiasm to institutionalization}

Three stages are commonly observed in the introduction of new sporting habits into a country or community: introduction, diffusion and institutionalization. As regards football, the first two stages happened quite spontaneously. However, institutionalization proved to be more problematic. In 1906, well after the first few matches were played, the Liga de Futebol ("Association Football League") was created, changing its name to the Liga Portuguesa de Football ("Portuguese Football League") a few years later. In 1910, the Associação de Futebol de Lisboa ("Lisbon Football Association") was founded, giving rise to the União Portuguesa de Futebol ("Portuguese Football Union"), with counterparts in Oporto and Portalegre, where there were also considerable English communities. The Federação Portuguesa de Futebol ("Portuguese Football Federation") appeared only in 1938.

Media reports from the first two decades of the $20^{\text {th }}$ century testify to the appearance of numerous playgrounds in Coimbra: Quinta de Santa Cruz, Quinta da Cumeada, Largo D. Luís, Campo Ínsua dos Bentos, Liceu Nacional de Coimbra, Escola Nacional Agrícola, Jardim Botânico, Campo da parada do Quartel de Santana, Campo da Arregaça, Campo do Arnado, Campo do Loreto. Clubs also sprouted up, such as the Sociedade de Esgrima e Gymnástica ("Fencing and Gymnastics Society"), Moderno Futebol Clube ("Modern Football Club»), Football Coimbra ("Coimbra Football"), Associação Académica de Coimbra ("Coimbra Academic Association"), Académico da Universidade ("University Academic"), Lyceu Football ("Football Lyceum"), Escola Agricola Football Clube ("Agricultural College Football Club"), Sport Club Conimbricense ("Coimbra Sport Club"), Olivais Futebol Clube ("Olivais Football Club"), Grupo Sportivo Progresso ("Progress Sport Group"), Grupo Desportivo da Fábrica Luzitânia("Luzitania Factory Sport Group"). Today, those playing fields have all been built over and the clubs have disappeared, victims of the gradual dehumanization of city centres. Unfortunately, there has been no corresponding creation of new pitches and clubs in the emerging communities.

\subsection{The importance of technical supervisors in the promotion of sports}

Basketball is an example of the intentional and planned introduction of a new sport into Portugal. It was the Associação Cristã de Estudantes [ACE - "Christian Students' Association] that took the initiative. Its aim was to provide students with opportunities for entertainment and leisure, to give them a break from academic pursuits and encourage socialization, bringing important intellectual and physical benefits.

On 20 June 1918, ACE inaugurated its headquarters in Coimbra under the direction of Mr. Myron Clark. Its first anniversary celebration included rounds of 
volleyball, basketball, boxing and tennis in the afternoon, and the speech that was given in the evening expressed the hope that it would soon be possible to contract a director of Physical Education. On 18 August 1920, Mr. Arthur Powlinson arrived in Coimbra to be first secretary of Physical Education, and in December 1921, a tournament was held between members, refereed by the directors Orton Clark and William Salling, who had certainly be forewarned about the lack of sportsmanship that usually characterised the city's football matches.

The official regulations of basketball were soon translated into Portuguese and published by the Orton Clark. The volume was considered essential for members, although there was no outside competition until 1924. Then in 1927, the secretary general of ACE called all local clubs to a meeting for the purpose of establishing a Basketball Association.

In less than seven years, basketball was introduced and institutionalized, while football took several decades to achieve the same status. This success was no doubt due to the efforts made by an already-existing organization that was prepared to supervise the sport and regulate competitions, even if the underlying purpose was to control the habits of an important social group, namely university students.

\section{Social changes in Portugal}

The resident population of Portugal was 5,960,056 in 1910. It rose to 7.76 million in the 1940 census during the Second World War, and increased again to 9.68 million in 1970 , when the country was finally democratised. This figure was very close to the 1990 population of 9.86 million.

At the same time, the fertility rate (i.e. the average number of children per woman 15-49 years) changed in the opposite direction, decreasing from 3.9 in 1930 to 2.1 in 1983. A fertility rate of 2.1 is necessary to ensure population renewal. The fertility rate is now well below the renewal value, reaching 1.6 in 1995 .

Population growth, then, was mostly due to the increased life expectancy. In 1990, life expectancy for men was 70.2 years, less than the 77.3 years for women. Corresponding estimates in 1920 were, respectively, 35.8 and 40.0 years, and in 1970 were, respectively, 64.2 and 70.8 years. This development was due largely to improvements in health care, reflected, for example, in the ratio of inhabitants per physician, 1,256 in 1960 and 352 in 1990). The sharp increase in life expectancy has inverted the age pyramid so that there are now large areas of the country, particularly in the interior, where the number of people over 65 exceeds the number under 15 .

Since the mid-1970s, Portugal began to receive immigrants, first from its ex-colonies in Africa, and more recently, following its accession into the European Economic Community, from Brazil and Eastern Europe. This migratory influx has been due, to a large extent, to a growing need for labour created by the application of European funds. At the same time, the economic structure of the country also changed, with a sharp reduction in the agricultural sector. In 1974, 1,287,000 persons were involved in agriculture but by 1994 , only 532,000 were so involved. This represents a loss of about 800,000 workers in this sector. This naturally had an effect upon health. The shift from being a country in which 1 in 10 of its inhabitants worked in agriculture, 
a physically active occupation, to one in which physical exertion is now largely a residual has meant that increasing levels of obesity and sedentarism have begun to be recorded.

As regards children and youth, there has been a sharp decline in child mortality, while compulsory schooling has increased from 4 to 9 years. The number of individuals attending elementary school increased from 106,998 in 1960 to 410,577 in 1994. This in turn has affected child labour, which was estimated at 84.2/1,000 in 1974 but which is now merely a residual. The economic shift from the primary to the secondary and, above all, tertiary sector of economic activities has also generated the need for a better educated labour force. Consequently, there has been an expansion in higher education in both the public and private sectors. At present, all 18 districts of the country have state higher education with a total of 13 polytechnics and 8 universities.

This demographic pull-factor has also served to accentuate the drain of people from the country to the cities. In 1990, approximately 3.5 million inhabitants (i.e. more than one-third of the population) resided in the demographic basins of greater Lisbon and Oporto alone. If the number of residents in the other 16 district capitals is added (about 1.2 million), it is apparent that one-half of Portuguese population resides in 18 urban centres within in a country of $96,052 \mathrm{~km}^{2}$.

\section{Current participation in organized sports}

\subsection{Participation in federations}

The first data published about the sports system in Portugal (Portuguese Institute of Sport, 2005) estimated that $3 \%$ of the country $(342,717$ in a population of $10,355,824)$ was members of sports federations. For the Autonomous Region of Madeira, the figure was $6 \%(14,090$ in a population of 245,012$)$. The corresponding estimate was $8 \%$ for the Autonomous Region of the Azores (18,816 of 241,762 inhabitants).

While participation in sports such as golf, pigeon racing, fishing and bridge can clearly continue across the life span, activities like gymnastics and swimming have a much more restricted period for participation. Sport-related human performances typically occur during a much shorter interval, usually from late adolescence into the late 20 s or early 30s, depending upon the sport and gender. Hence, the figures provided by official statistics for sports participation amongst the total population are limited since they do not take age into account.

\subsection{Annual variation of participation in federations}

Between 1996 and 2003, the membership of sports federations (a total of 65 federations) increased from 266,000 to 377,000 (Instituto do Desporto de Portugal, 2005), a gain of $42 \%$. More recent data show that the total membership of sports federations in Portugal continued to rise in 2004 to 398,511 (Ricardo, 2005). Closer examination of these estimates for the 2000-2004 Olympic cycle shows that the increase in the number of male participants was due to football $(+19,616)$, volleyball $(+17,190)$, handball $(+8,962)$ and gymnastics $(+8245)$, while that for female participants was due 
in volleyball $(+7,840)$, gymnastics $(+4,555)$, handball $(+4,159)$ and football $(+2,000)$. The estimates suggest that there may be still a demand for formal competitive sports that is not totally satisfied by the federations, even amongst traditional sports that date back to the second half of the $19^{\text {th }}$ and early $20^{\text {th }}$ centuries.

\subsection{Popularity of different sports in the federated sector}

Data for 2003 (Instituto do Desporto de Portugal, 2005) showed that football, which has 110,940 players enrolled in the respective federation, was the most popular sport, followed by handball (21,867 members) and basketball (19,800 members). Other federations with over 10,000 members were pigeon racing, athletics, volleyball, karate, skating and tennis.

\subsection{Public funding for sport federations}

Public funding for sport federations has largely kept up with the increase in the number of members. It increased from 27.4 million euros in 1996 to 36.5 million in 2003, and was at its highest in 1999, about 37.8 milion euros (Instituto do Desporto de Portugal, 2005). Despite the overall increase in state support via contracts, the amount spent by the state per athlete has dropped from 103 euros/athlete/year in 1996 to 97 euros/athlete/year in 2003. The highest figure recorded was in 1997, 128 euros/athlete/year. If inflation is taken into account, there was a decline from 103 to 78 euros/athlete/year between 1996 and 2003, a reduction of 24\%.

Although there appears to be a satisfaction in the political sphere with the increase in sports federation membership evident in the statistics, the data also show that the state budget has in fact failed to keep up with the increase.

\section{Participation of youth in sport}

\subsection{Youth under 16 registered in federations}

In 2004 , the number of youth under 16 years of age registered in sport federations was 207,034 of whom 157,050 were boys and 49,984 girls (Ricardo, 2005). This represents a $66 \%$ increase for girls and $35 \%$ increase for boys in the period 2000 2004. This segment accounts for $52 \%$ of the total membership, a proportion that is considerably higher than the $45 \%$ registered in 2000 . This suggests that the increase in sports participation is due mostly to the large-scale provision of sports instruction at early ages, despite a demographic drop of around 9\% in youth 10-16 years of age between 1991 and 2001.

The sports which expanded most in the 10-16 age group in terms of numbers of athletes were volleyball $(+17,155)$, football $(+16,702)$, handball $(+16,700)$ and gymnastics $(+7980)$. This may be due to several factors, such as the social impact of events like Gimnaestrada or the Euro-2004, as well as the appearance of quickconsumption packages with generalised appeal that require little specialized supervision, such as playgym or beach volleyball. 
Membership in federations such as for handball and gymnastics has also increased dramatically at this time through the promotion of programmes targeted to primary schools (1st to 4th grades). It is questionable, however, if this is the best way of introducing sports. In the school context, a fun-focused, rhythmic approach that aims to develop the body within a social and affective framework might perhaps yield better results. In this context, it is reasonably well known that early specialization often leads to a high dropout rate and premature exhaustion of individual capacities.

\subsection{Promotion and development of organized sports}

Given the increase in the number of subjects engaged in organized sport (from 266,000 to 377,000 between 1996 and 2003, and to 399,000 in 2004), it is surprising that there has not been a bigger increase in the number of clubs, instructors and referees. In 1996, there were 10,328 clubs in the competitive subsystem of federations, a figure which stabilized at 9,690 in 2003. The data concerning the number of coaches is even more intriguing. The number increased from 5,541 in 1996 to 13,304 in only two years, and then increased again to 16,353 in 2001 , before declining to 10,058 in 2002 and 9,735 in 2003.

An increase in the number of participants by $42 \%$ in only 7 years should have been accompanied by a parallel increase in the number of referees and judges; unfortunately this did not happen. Rather, the figure of 13,567 in 1999 decreased to 8,567 in 2003. The data might reflect the lack of reliable sport statistics, but also the inconsistency of sport developmental plans, focused excessively in the number of athletes.

\subsection{Transition to competition}

The 17-19 age group ('juniors') remained stable in the five years between 2000 and 2004. Increase in this segment was constrained by two important factors, entry into higher education or the work force. The number of males oscillated between 32,190 in 2000 and 31,758 in 2004, while there was a slight increase in the number of females from 7,963 to 10,731 over this interval.

This age segment is active in 55 of 65 sport federations and a decrease in numbers of participants was noted in 31, particularly in traditional sports such as basketball $(-2,161)$, gymnastics $(-1,041)$, table tennis $(-330)$ and handball $(-247)$. On the other hand, an increase in participants was noted in horse riding $(+531)$ and motorcycling $(+233)$. Aikido and taekwondo were among the 10 sports that registered the greatest absolute increases in the number of junior participants.

It would appear that the increase in sport participation was due mainly to the success of large scale or mass sport initiation at the young ages. This inevitably inflates the number of participants but such increases need to be viewed with care. Pre-teens can be viewed as "false athletes" in the sense that they do not progress to specialized training that is more demanding in terms of technical resources, training conditions and competition resulting in a high dropout rate. Further, lifestyle changes in the late teens tend to favor other non-sporting interests. The data may reflect a change in the sporting habits of the Portuguese population, from organized and competitive settings to occasional events (this will be analyzed later in this article). 


\subsection{Summary of school sports statistics}

School sport has been perceived as an under-exploited tool by the sport system. There are some 866,000 young subjects in elementary and high schools (more than double the number of federation members - 399,000 in 2004), while the total number of schoolchildren engaged in school sport is around 119,760 (data from 2001/2002). The number of individuals under 17 years (i.e., not juniors) registered in federations was 185,586 in 2004 . If federated sports were confined to juniors and seniors, there would be total of 169,550 athletes. With funding of federations at a level of 36.5 million euros, the nominal amount per member would be 215 euros/athlete (juniors and seniors).

Presently available data suggest that school sport can provide participation for approximately 120,000 young people at a little over 3 million euros, resulting in a figure of 25.3 euros/student/year. About 30 million euros should be added to this figure expenditure due to an increase of around 1,000 Physical Educators for the $5^{\text {th }}$ to $12^{\text {th }}$ years of schooling. In Portugal, sport is voluntary for Physical Education teachers, and those who participate in sport are compensated with a reduction in academic responsibilities. Teachers at the start of their career have a timetable of 35 hours/week, of which 22 are lessons. Previously, school sport was paid as overtime work.

In accordance with data provided by governmental departments, income from the national lottery decreased by $37 \%$ from 4.0 million euros in 1999 to 2.5 million in 2002. The dependence of school sport upon the income generated by lottery produces enormous fluctuations in the overall funds available: 3,416,765 euros in 1998; 4,249,478 in 1999; 4,083,213 euros in 2000; 3,182,690 euros in 2001 and $3,032,691$ in 2002 .

\section{Complementary data on sporting habits}

Since the 1980s, several European countries have joined to study the sporting habits of their respective populations in projects such as in the COMPASS programme (1999). Marivoet (2002) briefly summarized the results for Portugal showing that the average level of participation remained unaltered at 27\% between 1988 and 1998 . This figure was similar to other countries in southern Europe, such as Spain and Italy, which registered $31 \%$ and $23 \%$, respectively. The highest rates of participation were reported in Finland (81\%), Sweden (70\%), United Kingdom (67\%), Ireland (64\%) and Holland (63\%).

The Portuguese figure of $27 \%$ can be partitioned into $5 \%$ in federated sport and $22 \%$ in leisure sport. These estimates were calculated from a survey of a stratified proportional sample of the population between 15 and 74 years of age using the following question: "How do you spend your free time?». Responses were based upon a list that included items such as "watching TV», "reading», "doing sport», "going to the cinema», etc. [Note, individuals under 16 years of age account for the largest proportion of participants in organized sports offered by federations in Portugal so that the estimate for sport participation provided by this survey is not free of potential criticism.] 
It should be noted that some countries used a different age range for the study so that comparisons need to be made with care. In Sweden, for example, the age range was 7 to 70 years, while in Finland the population above 3 years of age was included.

\subsection{The satisfied and unsatisfied demand for sport}

The 5th question in the survey reported by Marivoet (op.cit) was the following: "Could you tell me what sports or physical activities you do?» Answers were based upon a list of 63 sports and physical activities. Although the list included activities such as fitness, which involves options like power walking and jogging, a considerable portion of the adult population (particularly the less well-educated or culturally less developed) tend to indicate athletics when they mean going for a run, football when they are merely kicking the ball around, or swimming when they are splashing about in a pool. In Portugal, the term 'gymnastics' is often understood as a synonym for Physical Education or even for sport, particularly amongst older people; while riding around on a bicycle is frequently confused with the sport of cycling. Allowing for these limitations, the list of most popular sports is worth noting. Football, swimming, athletics, fitness activities, gymnastics and cycling topped the list.

The survey also asked respondents who did not do any sport if they were considering taking one up, and if so, which one. This provided a universe of potential demand for sport corresponding to $4 \%$ of the population, with swimming (36\%), gymnastics $(15 \%)$ and dance $(13 \%)$ indicated as the most desired activities. It is not known whether the result of this survey would impact the number of public swimming pools nation-wide. In general, facilities are usually of a competitive format to enable them to be used for federations, which means that they are not always suitable for the range of water activities that interest the public at large.

As regards youngsters, occasional studies, such as that carried out by the Cantanhede Council (Coelho e Silva et al., 2002) suggested that there is substantial potential for the promotion of traditional sports such as basketball, football and swimming, as well as a demand amongst adolescents for activities such as aerobics, bodybuilding, outdoor activities (mountain bike, bodyboard) and motor-related (karting and motorcycling).

\subsection{Ecological dimension of sport participation}

The survey of the Portuguese population also suggested that sports participation was highest in habitats of 5,000 to 10,000 people, due mostly to a lower dropout rate (Marivoet, 2001). Cities of over 20,000 inhabitants had broader coverage (sum of people currently and formerly participating in sports), but also had a higher dropout rate.

It is well known that time-management is among the main obstacles to regular sports participation, particularly when sport has to be reconciled with studies or work. This is the case not only among participants (Coelho e Silva \& Garcia Silva, 2003) but also coaches (Coelho e Silva et al., 2006).

Additional studies have shown that children in urban areas are less independent socially and less able to get around autonomously (Colaço, 2006). For this reason, participation in sports requires more family support, even between the ages of 12 and 16 (Auxiliar, 2006). This latter study also showed that average-sized communities 
are the most propitious for participation in sport. They are large enough to actually possess sport facilities and also permit friendly mobility between residence, school and sport practice both in terms of time consuming and of safety.

\subsection{Sport for adults in non-competitive settings}

In alternative to sports federations, the Instituto Nacional de Tempos Livres ("National Institute for Leisure and Free Time", INATEL) provides opportunities for sports participation that seem to suit the sporting needs of the population. INATEL offers several programs for participation such as: a) organization of regular competitions, b) regular supervised non-competitive physical activities, c) organization of occasional events within a "Sport for All" perspective, d) non-traditional outdoor activities.

According to recent non-published reports, about 31,000 subjects (mostly males) participated in the first group of competitive sporting activities. This format is much less formal than federated sports. The most popular sports were athletics, swimming, fishing, table tennis, shooting, chess, handball, football, basketball, volleyball and beach volleyball.

A second group involved 14,369 adherents, including a considerable number of women. Aerobics, fitness swimming and hydro-gymnastics were the most prominent activities.

The "sport for all" activities attracted 126,805 participations. Less traditional outdoor activities such as paragliding, climbing, orienteering, mountain biking, involved 45,470 participations. In the last two categories, participants refer to the total number of entries taking part in the programs. It is possible that participants could be represented more than once.

Although specifics of the INATEL budget is not available, it is well known that in this sector of sporting system, the amount of administrative and technical staff is very small. Its activities are largely financed by the participants themselves.

\section{New trends for the following decades}

\subsection{The new hygienism}

In a sample of 4,511 Portuguese children 7.0 to 9.9 years, the prevalence of overweight was $20.3 \%$ and that of obesity was $11.3 \%$ using the criteria of the International Obesity Task Force (Padez et al., 2004). Thus, almost 1 in 3 Portuguese children need to lose body mass.

The International Obesity Task Force recommends cut-off values suggested by Cole et al. (2000). These correspond to BMIs of $25.0 \mathrm{~kg} / \mathrm{m}^{2}$ and $30 \mathrm{~kg} / \mathrm{m}^{2}$, determined from 2 to 18 years of age, separately for each sex, at six month intervals. This study made use of a database from six developed countries in three continents. European data were from England and The Netherlands where adult populations are, on average, substantially taller than Portuguese adults. Moreover, in these countries, the trend for increased height over generations has stabilized some decades ago while in Portugal there are as yet no signs that the genetic growth potential has been reached. 
Although there may be reservations about using cut-off points for overweight and obesity based on from other countries, the statistics on overweight and obesity for Portuguese children are, nevertheless, of concern. Further, a study of geographic variation in sedentary lifestyle in Europe noted that Portugal was one of the countries where people were markedly less active (Varo et al., 2003). By inference, the increase in overweight and obesity may reflect reduced levels of physical activity in the population beginning at pediatric ages.

In the light of these "social alarms" combined with results of studies of health service expenditures related to sedentarism and obesity, the importance of sport has been reiterated in health campaigns, with a view to achieving benefits in the area of public finances.

In the United States, the direct cost of a lack of physical activity was estimated at around 24 billion dollars (Colditz, 1999), while in Canada the estimated cost of physical inactivity to the economy was 5.3 billion dollars and that of obesity was 4.3 billion dollars (Katzmarzyk \& Janssen, 2004).

This new medical dimension of sport is also known as the Neo-Hygienism. In a sport system where funds are limited, it is not surprising that the extension of the aims of sport (the Sports Act became known as the Sport and Physical Activity Act) should result in even tighter restrictions upon the resources available for the traditional sector (i.e. sports federations).

\subsection{Municipalization of sports}

It is evident that public funding for sport federations has stagnated at around 40 million euros per year. In parallel, a disinvestment is apparent in school sport. Sport is strongly dependent on incomes generated by lotteries. The vacuum left by the withdrawal of the central government has, in the case of sport, been largely filled by local authorities. In Portugal, of the ten stadiums built to host the European Cup in 2004, four belong to football clubs and six to local councils. The same phenomenon can be seen with the construction of swimming pools and tracks for athletics. The central government in Portugal owns very few sports facilities, even those of national or international importance.

Local authorities presently have the majority ownership of the national sports park. The lack of planning as regards investment in sports facilities is clearly exemplified by the construction of stadiums that are oversized in relation to the importance of their local clubs. Obviously, a town needs to be of a minimum size to justify the construction of facilities that may be costly to run. There may be serious difficulties in maintaining facilities that have been built without concern for the needs of the local populations, such as those constructed in areas where the population is dramatically aging.

\subsection{Americanization of sport}

Szymanski \& Ross (2000) consider that the main difference between the structure of American and European professional leagues has to do with openness. In Europe, access to important leagues such as football is dependent upon sports; on the other 
hand, in the United States, the main leagues operate as franchises and teams are formed with a view to conquering the market.

An analysis of the location of NBA (basketball), MLB (baseball), NFL (American football) and NHL (ice hockey) league franchises showed that there were no teams in metropolitan areas with less than 1 million inhabitants (Durant et al., 2006). Moreover, only five cities had clubs in all leagues and more than one club in the same league. These were New York (20.14 million inhabitants), Los Angeles (15.97 million inhabitants), Chicago (8.87 million inhabitants), Washington D.C. (7.36 million inhabitants), San Francisco (6.91 million inhabitants).

The lack of teams representing large cities like Los Angeles, Chicago and New York in the recent finals of the NBA championships is a concern for the league managers. In the constant search for greater profits, the NBA has expanded to include important Canadian cities, while David Stern - NBA general manager - has also studied the potential of certain European cities. Interestingly, the general manager ignored PauOrthez, Limoges, Vittoria and Treviso, despite the fact that they have the most powerful basketball teams in Europe. Instead, the expert suggested that teams should be formed in London, Paris and Berlin, where basketball is not yet really established.

The European Basketball League (ULEB) has set up a competition in which access is by multi-year invitation in order to attract powerful investors. This compromise between sporting and economic criteria is typical when clubs orient their activities towards international events, where there is large-scale television coverage and sponsors have a much greater impact. In football, this is taken to such an extent that important players are being saved in the internal leagues.

A list of European metropolitan areas ranked by size is led by Paris with 9.32 million inhabitants, followed by Moscow (8.64 million), London (7.69 million) and Istanbul (5.48 million); Lisbon and Oporto rank $18^{\text {th }}$ and $37^{\text {th }}$, respectively, with 2.32 million and 1.15 million inhabitants (Durant et al., 2006). The authors anticipate that the Soccer Champion's League will increase in importance while national leagues will decline, with the possibility that intermediate leagues may be set up (suggesting a regionalized Europe) to ensure that clubs in the small and medium-sized towns will remain economically viable. Interest of Anderlecht to participate in the French league, and of Glasgow "Old Firm» (fusion of Celtic and Rangers) to compete in the English Premier League was mentioned as well as the possible merger of the Swiss and Austrian championships, and even the creation of an "Atlantic League» involving clubs from Portugal, Holland, Belgium and Denmark. In other words, national competitions need to gain scale as a survival strategy, so as not to be overshadowed by the Champion's League.

Access to the Champions League creates such an economic dynamic that clubs participating in it are substantially apart from others that compete only in domestic events (Hoehn \& Szymansky, 1999). According to these authors, this imbalance is damaging national leagues. It would be preferable for clubs with international aspirations to be separated from internal games, creating more competitiveness and uncertainty, and allowing winners to rotate in domestic leagues.

The entie logic of sport will, therefore, be altered. The results of national leagues, which have always had symbolic value for traditional fans, will also be oriented towards economic interests. Older clubs will no longer be maintained but instead will have to 
depend upon the investment and disinvestment strategies of their shareholders. Eclectic clubs offering a range of different sports will concentrate their activities on business areas defined by their shareholders, dropping sports that are not viable economically, even if they are still relevant in social and sporting terms.

\section{Concluding remarks}

The "sportification" of society is clearly evident in the growing use of sport as a marketing instrument. The traditional concept of sport is changing into a TV entertainment industry based mostly on top athletes of those sports that possess the ability to attract more viewers and therefore to make sport economically more profitable. This process of differentiation into less boring events is termed the "commodification" of sports.

Changes are also occuring in the situation of sport as a leisure activity with immediate enjoyment, relaxation and recreation as its main characteristics. These alternative sports have been called "nonsporting sport" (Dietrich \& Heinemann, 1989). This trend results in increased competition between the growing number of sports, sport organizations and settings in which sports can be practiced and commercialized. This development has been labeled as the "desportification of sports" (Crum, 1991). As a result of these trends, the actual content and meaning of sport in general has become less clear and in turn demands ongoing research and analyis.

\section{References}

Adelino J, Vieira J, Coeho O (2005). Caracterização da prática desportiva juvenil federada [characterization of youth sport]. Lisboa. Instituto do Desporto de Portugal.

Auxiliar N (2006). Grau de urbanização e apoio das famílias à participação desportiva de crianças e jovens [Degree of urbanization and familial support to sport participation of children and youth]. Master dissertation. University of Coimbra.

Barreto A (1997). A situação social em Portugal 1960-1995 [Social situation in Portugal 1960-1995]. 3rd Edition. Instituto de Ciências Sociais da Universidade de Lisboa.

Barroso M (2001). História do ciclismo em Portugal [History of cyclism in Portugal]. Lisboa. CTT - Correios de Portugal.

Coelho e Silva M (2002). Morfologia e estilo de vida na adolescência [Morphology and lifestyle in adolescence]. PhD dissertation. University of Coimbra.

Coelho e Silva M, Garcia da Silva N (2003). Procura desportiva satisfeita e razões para o abandono da prática desportiva na população jovem da ilha do Faial [Sport participation and reasons for discontinuing among youth of Faial - Azores Islands]. Ludens - Ciências do Desporto. Vol. 17 (3): 11-20.

Coelho e Silva MJ, Casas de Melo EH, Gonçalves CE, Albuquerque E, Oliveira H, Teixeira M, Carmo Freitas N, Mortágua P (2004). Plano Estratégico de Desenvolvimento Desportivo do Concelho de Cantanhede [Sport development plan in Cantanhede]. Município de Cantanhede.

Coelho e Silva MJ, Lamy Rocha I, Gonçalves CE (2006)._Treinador de jovens e formação de jovens treinadores. In MJ Coelho e Silva, CE Gonçalves, A Figueiredo (Eds). Desporto de Jovens ou Jovens no Desporto? [Youth sports or youth in sports?] (pp.183-196). Faculdade de Ciências do Desporto e Educação Física - Universidade de Coimbra, Instituto do Desporto de Portugal. 
Colaço S (2006). Rotinas de vida e independência de mobilidade de crianças do $2^{\circ}$ ciclo do Ensino Básico em dois contextos sociais diferentes [Living habits and mobility autonomy among youth from two different social contexts]. Master dissertation. University of Coimbra.

Colditz GA (1999). Economic costs of obesity and inactivity. Medicine and Science in Sports and Exercise. Vol.31 (11): S663-S667.

Cole TJ, Bellizzi MC, Flegal KM, Dietz W H (2000). Establihing a standard definition for classification of overweight and obesity. British Medical Journal. 320:1-6.

COMPASS (1999). Sports participation in Europe. London. UK Sport.

Crum BJ (1991). Over Versporting van de samenlving [about the sportification of society]. Rijswijk. The Netherlands. WVC.

Dietrich K \& Heinemann K (1989). Der nicht-sportliche sport [the nonsporting sport]. Schorndorf, Germany. Hofmann.

Durant C, Ravenel L, Bayle E (2005). The strategic and political consequences of using demographic criteria for the organization of European leagues. European Journal of Sport Science. Vol. 5 (4): 167-180

Gerardo F, Gomes Ferreira A (2002). As origens do movimento desportivo na cidade de Coimbra [The origins of sport in the city of Coimbra]. In F Sobral, M Coelho e Silva (editores). Demografia e jovens no desporto. (7-30) Lisboa. Ministério da Juventude e Desporto.

Gouveia L (2002). História do hóquei em patins em Portugal [History of roller hockey in Portugal]. Lisboa. CTT - Correios de Portugal.

Guia oficial da missão olímpica de Portugal (2004). Olimpo - Revista do Comité Olímpico de Portugal. $\mathrm{N}^{\circ}$ 111.

Hoehn T, Szymansky S (1999). The americanization of European football. Economic Inquiry, 28, 205233.

Instituto do Desporto de Portugal (2005). Estatísticas do associativismo desportivo [Statistics of Sports]. Lisboa. Instituto do Desporto de Portugal.

Katzmarzyk PT, Janssen I (2004). The economic costs associated with physical inactivity and obesity in Canada - an update. Canadian Journal of Applied Physiology. Vol. 29 (1): 90-115.

Marivoet S (2001). Hábitos desportivos da população portuguesa [Sporting habits in the Portuguese population]. Lisboa. Instituto Nacional de Formação e Estudos do Desporto, Ministério da Juventude e Desporto.

Marivoet S (2002). Hábitos desportivos da população portuguesa: 1988-1998 [Sporting habits in the Portuguese population: 1988-1998]. In Actas das III Jornadas de Sociologia do Desporto organizadas pela Secção de Sociologia do Desporto da Associação Portuguesa de Sociologia. Lisboa. Centro de Estudos e Formação Desportiva, Secretaria de Estado da Juventude e Desportos.

Padez C, Fernandes T, Mourão I, Moreira P, Rosado V (2004). Prevalence of overweight and obesity in 7-9-year-old Portuguese children. American Journal of Human Biology. 16: 670-678.

Ricardo H (2005). Desporto federado no ciclo olímpico 2000-2004. Revista Desporto. 3: 4-13

Szymanski S \& Rosd S (2000). Open competition in league sports. Wiscosin Law Reviews, 625-656.

Varo JJ, Martinéz-Gonzaléz MA, Irala-Estévez J, Kearney J, Gibney M, Martinéz JA (2003). Distribution and determinants of sedentary lifestyles in the European Union. International Journal of Epidemiology. 32: $138-146$. 